УДК 37.013

Режим доступу до журналу: http://www.journal.iitta.gov.ua

Бугайчук Костянтин Леонідович, кандидат юридичних наук, доцент, провідний науковий співробітник науково-дослідної лабораторії 3 проблем профілактики правопорушень та взаємодії 3 населенням, Харківський національний університет внутрішніх справ, м. Харків, e-mail: klbugaychuk@gmail.com

\title{
МАСОВИЙ ВІДКРИТИЙ ДИСТАНЦІЙНИЙ КУРС: ПОНЯТТЯ, ОСОБЛИВОСТІ ПРОВЕДЕННЯ ТА ПЕРСПЕКТИВИ ВИКОРИСТАННЯ В НАВЧАЛЬНОМУ ПРОЦЕСІ СИСТЕМИ МВС
}

\section{Анотація}

Оскільки освітні технології все більш поширюються через соціальні мережі й мобільні пристрої, виникають спроби знайти методики, які грунтуються на цих нових технологіях для поліпшення навчального процесу - масові відкриті дистанційні курси є одним із таких форматів. Автором статті проаналізована сутність і структура масових відкритих дистанційних курсів, а також особливості їх проведення. На підставі аналізу публікацій закордонних дослідників і власного досвіду сформульовані принципи побудови i діяльності учасників масових відкритих дистанційних курсів. Також у статті окреслені основні напрями застосування масових відкритих дистанційних курсів у освітній діяльності системи МВС України.

Ключові слова: навчальний процес, масовий відкритий дистанційний курс, конективізм.

Постановка проблеми. Сучасна концепція освіти впродовж всього життя набуває особливого значення. Вона є відповіддю на виклик, який кидає нам світ, де зміни відбуваються дуже швидко. Для кожної людини безперервна освіта має стати процесом формування i задоволення іiі пізнавальних запитів, духовних потреб, розвитку здібностей у різних навчальних закладах за допомогою різних форм навчання, a також шляхом самоосвіти i самовиховання. Безперервна освіта розвивалася як феномен практики і як педагогічна концепція. Вперше ця ідея була концептуально оформлена на конференції ЮНЕСКО у 1965 р. відомим теоретиком безперервної освіти П. Ленграндом [1]. 
За останні десятиліття кардинально змінилася система генерації й передавання інформації, а її обсяг значно зріс. Згідно із сучасними реаліями не можна навіть за 5 або 6 років, підготувати людину до професійної діяльності на все життя. Нині щорічно оновлюється близько $5 \%$ теоретичних і $20 \%$ професійних знань. Одиниця вимірювання старіння знань фахівця, прийнята у США - період «напіврозпаду» компетентності, тобто зниження її на 50 \% внаслідок появи нової інформації, виявляє, що стосовно багатьох професій цей період настає менше ніж через 5 років, тобто відносно нашої системи вищої освіти цей процес відбувається раніше, ніж закінчується навчання.

Найбільш ефективно концепцію безперервної освіти реалізують інформаційнокомунікаційні технології, широке застосування яких привело до виникнення таких явищ, як відкрита освіта, дистанційне навчання тощо. Не вдаючись до детального аналізу вищезазначених дефініцій, маємо зазначити, що останні 5 років у галузі організації дистанційного навчання спостерігається тенденція до пошуку оптимальних форм масового навчання, яке реалізувалося у виникненні поняття «масовий відкритий дистанційний курс», особливості якого ми й спробуємо розкрити в нашій публікації.

Аналіз останніх публікацій. Застосування масових відкритих дистанційних курсів останнім часом широко використовується у закордонній педагогічній практиці. Основою розвитку цього напрямку є роботи теоретиків конективізму Стівена Доунса $\mathrm{i}$ Джорджа Сіменса [2-4]. Підсумки роботи в цих курсах можна зустріти в публікаціях інших авторів [5-7]. На теренах країн СНД відповідних досліджень немає взагалі й подібні курси не спостерігалися. Однак протягом 2011 року на Україні відбулася спроба провести такі відкриті курси. Ініціатором першого заходу «Стратегія е-learning в організації» виступив професор Кухаренко В. М. Другий курс «Соціальні сервіси у дистанційному навчанні» був проведений Кухаренком В. М. спільно з автором цієї публікації.

Мета статті полягає у здійсненні аналізу сутності відкритих дистанційних курсів, їх особливостей і перспектив застосування в освітній діяльності МВС. 
Викладення основного матеріалу. Взагалі поняття дистанційного курсу не дуже часто наводяться в науковій літературі, проте, для всіх здебільшого, зрозуміла його структура і тому ми можемо навести деякі його визначення.

Дистанційний курс - це аналог навчально-методичного посібника для студентів, що навчаються за традиційною заочною формою й екстернатом. Фактично дистанційний курс - це розроблена з певним ступенем повноти покрокова інструкція з освоєння курсу, тобто з досягнення цілей, сформульованих у його описі [8].

У процесі дистанційного навчання використовуються дистанційні курси інформаційні продукти, які є достатніми для навчання за окремими навчальними дисциплінами [9]. Дистанційний курс - це запланована викладачем діяльність для засвоєння структурованої інформації [10].

У Проекті Положення про сертифікацію електронного навчального курсу (а фактично тут мається на увазі дистанційний курс) вказано, що електронний навчальний курс (ЕНК) - це комплекс навчально-методичних матеріалів й освітніх послуг, створених для організації індивідуального i групового навчання 3 використанням дистанційних технологій [11].

Електронний курс є структурованим матеріалом 3 тієї чи іншої теми, що вирішує заздалегідь визначені цілі навчання [12].

Взагалі то кажучи, у теорії академічного i корпоративного навчання розрізняють поняття «електронного» i «дистанційного» курсу, але для авторів наведених визначень, ці прикметники є синонімами. Зазвичай, дистанційний курс складається з таких навчально-методичних елементів.

- Статичний блок: передмова (стисла інформація про курс, його елементи, практичну спрямованість, умови та тривалість навчання, відомості про авторів курсу тощо); методичні рекомендації щодо роботи 3 дистанційним курсом; робоча навчальна програма 3 тематичним (тижневим) плануванням; навчальні теми; практичні і тестові завдання; дискусійна діяльність, яка реалізується у вигляді форуму або чату.

- Динамічний блок. Сенс полягає у діяльності певного кола спеціалістів (тьюторів, програмістів, web-дизайнерів тощо). Він включає: доставку слухачеві навчальних матеріалів (або забезпечення доступу до них); забезпечення необхідної адаптації на початку навчання і мотивації впродовж усього навчального процесу; 
організацію самостійної роботи слухача щодо засвоєння навчального матеріалу, організацію практичної допомоги слухачеві під час опанування ним матеріалу курсу; самооцінювання і контроль знань, умінь і навичок слухачів; технічну підтримку дистанційного курсу тощо [13].

Що ж до структури масового відкритого дистанційного курсу, то він дещо відрізняється від традиційного дистанційного курсу.

Термін «масовий відкритий дистанційний курс» (Massive Open Online Course MOОС) запропонували два дослідники Брайан Александр і Дєйв Кормьє в результаті роботи над курсом «Connectivism \& Connective knowledge», який у 2008 році проводили Джордж Сіменс і Стівен Доунс. Загальна назва курсів цього типу утворюється з чотирьох окремих термінів, про які варто розповісти дещо повніше.

Massive (масовий) - для проведення цього курсу потрібна велика кількість учасників, як показує практика тільки 10-15\% учасників, що зареєструвалися, активно працюють, тому для оптимальної роботи і генерації інформації потрібно від 30 до 50 активних учасників. Open (відкритий): курс $є$ безоплатним і будь-хто і в будь-який момент може приєднатися до нього. Online (дистанційний тип онлайн) означає, що матеріали курсу і результати спільної роботи знаходяться в мережі Інтернет у відкритому для учасників доступі. Course (курс): мається на увазі, що він має назву, відповідну структуру, правила роботи та загальні цілі, які згодом для кожного учасника можуть трансформуватися. Відкриті дистанційні курси спираються на низку принципів, що випливають з теорії конективізму:

Принцип агрегації. Весь сенс курсу полягає в тому, що він є відправною точкою надання інформації за відповідною темою, причому ця інформація може розміщуватися в різних місцях, а сторінки курсу виступають як своєрідний агрегатор, який може змінюватися протягом навчання, що, зазвичай, не робиться у академічних курсах.

Принцип реміксу. Матеріали курсу органічно пов’язані один з одним, але можуть мати інші зв’ язки поза курсом.

Принцип розповсюдження. Учасники обмінюються думками й інформацією не тільки між собою, а з усім цифровим світом.

Принцип перепрофілювання. Кожний учасник використовує інформацію відповідно до власних навчальних цілей. 
Згідно із зазначеними принципами, курс «Connectivism \& Connective knowledge 2008» був безоплатним (хоча слід зазначити, що там передбачалася платна опція, яка була пов'язана з отриманням сертифіката студентами університету Манітоби). На цей курс підписалося близько 2200 осіб, 150 з котрих і надалі постійно взаємодіють один 3 одним. Матеріал курсу було розміщено за принципом гіперпосилань, основну сторінку зроблено за допомогою WordPress - платформи для побудови блогів й Інтернет сторінок, для спілкування використовувався форум у LMS Moodle, а для загального опису курсу і створення методичних рекомендацій щодо навчання в ньому використовувалася платформа Wiki.

Учасники курсу, які платили за проходження курсу i мали отримати сертифікат, повинні були щонеділі писати власні враження й розміщувати інформацію у своїх блогах, брати участь у форумах і коментувати репліки інших слухачів, накреслити концептуальну схему (карту), направити 3 рефлексивних листи (500-750 слів) і зробити заключну презентацію (відео, підкаст) за тематикою курсу.

Кожного тижня висвітлювалася нова тема з гіперпосиланнями на відповідну інформацію. На початку тижня організаторами робилося розсилання на електронні адреси $з$ посиланнями на інструктивні підкасти (презентації, відео) за тематикою тижня - так званий вступ, наприкінці тижня виходив бюлетень курсу - агрегатор із посиланнями на роботу учасників у блогах, форумах, а також коротким резюме.

Щосереди планувалися обговорення за допомогою платформи Elluminate, на які також запрошувалися гості, що робили короткі доповіді за темою тижня, що потім обговорювалися учасниками дискусії. Щоп'ятниці на платформі Ustream відбувалося заключне обговорення результатів діяльності учасників курсу на поточному тижні. Роль організаторів цього курсу зводилася до підтримки дискусій, узагальнення діяльності учасників, забезпечення зворотного зв'язку, вирішення технічних питань.

Серед подібних дистанційних курсів також слід визначити:

- Connectivism \& Connective knowledge (ССК09) (13.09.2009 - 06.12.2009);

- Personal Learning Envronments Networks and Knowledge (PLENK10) (13.09.2010-21.11.2010);

- Connectivism \& Connective knowledge (CCK11) (17.01.2011 - 11.04.2011);

- Learning and Knowledge Analytics (LAK11) (10.01.2011 - 20.02.2011); 
- Online Learning Today... and Tomorrow (eduMOOC11) (27.06.2011 22.08.2011).

Деякі статистичні дані масових відкритих дистанційних курсів Connectivism \& Connective knowledge (ССК), проведених у 2008-011 роках.

- Блоги: CCK11 - 870 повідомлень у блогах.

- Соціальні закладки у сервісі Delicious: CCK11 - 712 закладок, CCК09 851 закладка, ССК08 - 1965 закладок.

- Соціальні закладки у сервісі Diigo: CCK11 - 46 учасників, 120 закладок, 310 відвідувань; ССК 08 і 09 - 60 учасників, 180 закладок, 288 відвідувань.

- Facebook: CCK11 - 129 членів, ССК09 - 23 члени, ССК08 - 427 членів.

- $\quad$ Friendfeed (агрегатор інформації з різних соціальних сервісів): ССК09 - 58 членів, ССК08 - 43 члени.

- $\quad$ Групи Google CCK08 - 333 члени, 252 повідомлення.

- Twitter: CCK 11 - 6201 твітів, 906 учасників, 3516 URL-адрес [14].

Західні дослідники виділяють такі переваги і недоліки масових відкритих дистанційних курсів (МООС)

\section{Переваги}

1. Можливість організації такого курсу в будь-яких умовах, де наявний зв’ язок (Інтернет або локальний зв’язок, наприклад, Wi-Fi).

2. Можливість організації курсу будь-якою мовою (з урахуванням основної мови вашої цільової аудиторії).

3. Можливість використання будь-яких online інструментів, що мають відношення до вашої цільової аудиторії або які вже використовуються учасниками в повсякденній і професійній діяльності.

4. Можливість виходу за межі часових поясів і фізичних кордонів.

5. Можливість швидкої організації такого курсу, яка дорівнює швидкості повідомлення учасників про їх відкриття.

6. Навчання відбувається в більш неформальній обстановці.

7. Контент може бути відкритим для всіх.

8. Навчання здійснюється завдяки неформальним знанням, які створюються в курсі завдяки обміну інформацією і досвідом між його учасниками. 
9. Можливість використовувати ці курси як в корпоративному, так $\mathrm{i}$ в академічному секторі.

10. Можливість створення власного персонального навчального середовища $\mathrm{i}$ власної персональної навчальної мережі за допомогою учасників курсу.

11. Можливість поліпшення своїх навичок щодо навчання протягом всього життя, адже ці курси змушують вдосконалюватися і розвиватися.

12. Після закінчення курсу його інформація не видаляється - тобто створені навчальні мережі є більш стійкими.

\section{Недоліки}

1. Хаотичність і велика кількість інформації.

2. Навчання в МООС потребує навичок володіння комп’ютером.

3. Кожний учасник сам визначає свої навчальні цілі і самостійно регулює свою діяльність в курсі.

4. Кожний учасник курсу будує власну траєкторію навчання [15].

У цьому році професором НТУ ХПІ Кухаренком В. М. було проведено 2 дистанційних курси за принципами MOOC: «Стратегія e-learning в організації» i «Соціальні сервіси у дистанційному навчанні» - автор цієї публікації був учасником першого курсу, а також організатором і тьютором другого курсу.

Декілька слів про організацію роботи у відкритому дистанційному курсі «Соціальні сервіси у дистанційному навчанні».

Цільова аудиторія курсу -- викладачі, аспіранти, керівники освітніх структур різних організацій. Учасникам бажано б було мати навички роботи в Інтернеті, соціальних мережах і веб-комунікаціях (синхронних і асинхронних). У результаті активної участі протягом усього курсу учасники створили власні персональні навчальні середовища, сформували персональні навчальні мережі, опанували соціальні сервіси, які необхідні для розробки дистанційного курсу і проведення дистанційного навчального процесу.

Основна платформа для розміщення інформації й інструктивних матеріалів Wikispaces. У ній знаходилися гіперпосилання на інформаційні ресурси за тематикою курсу відповідно до тижневого планування. Для кожного інформаційного ресурсу учасникам спільноти були відкриті можливості редагування сторінок і створення 
нових тем. Теми кожного тижня мали декілька дискусійних форумів, причому нові теми міг запропонувати (створити) кожний слухач курсу.

Кожного тижня, окрім праці над інформаційними ресурсами, для виконання пропонувалися практичні завдання. Кожному учаснику запропоновано було створити власний блог, зареєструватися в соціальних мережах Twitter, Diigo, завести поштову скриньку на Gmail, приєднатися до спільноти на Googlegroups. Для проведення online зустрічей була вибрана платформа вебінарів Wiziq.

На головному порталі курсу були створені інструктивні сторінки щодо роботи в курсі, окремі сторінки із записами проведених вебінарів, архіви форумів учасників. Щотижнево організаторами курсу готувався інформаційний бюлетень із підсумками роботи спільноти за минулий тиждень й інструкціями щодо роботи на наступному тижні. Слухачі курсу вивчали інформаційні ресурси курсу, після їх опрацювання вони могли публікувати свої думки щодо наданої інформації, а також виконувати завдання у власних блогах i на сторінках соціальних мереж. Учасники шукали нову інформацію про соціальні сервіси, їх зміст, особливості роботи 3 ними і напрями використання в навчальному процесі. Цю інформацію вони оформлювали у вигляді відеороликів, публікацій у блогах, посиланнях у Twitter, Facebook, Googlegroups, закладках Diigo, а також, залишаючи інформацію в самій платформі Wikispaces на сторінці відповідної теми.

\section{Статистичні дані відкритого дистанційного курсу «Соціальні сервіси у}

\section{дистанційному навчанні»}

- Електронна адреса: http://el-ukraine.wikispaces.com.

- Тривалість курсу 6 тижнів: 23.05.2011 - 03.07.2011.

- Зареєструвалося учасників у wikispaces.com: 44.

- Зареєструвалося у Google групі E-learning в Україні: 41, повідомлень - 41 (Інтернет адреса: https://groups.google.com/group/e-learningukr?hl=uk).

- Соціальні закладки в Diigo: зареєструвалося 10 осіб, зроблено 111 закладок за час тривалості курсу.

- Проведено вебінарів: 7 (у середньому на вебінарі були присутніми 12 слухачів).

- Переглядів усіх сторінок у wikispaces.com членами спільноти - 11911 . 


\section{Статистика курсу за відвідуваннями з глобальної мережі Інтернет (інформація станом на 20 вересня 2011 року):}

- відвідувачів курсу (за унікальними IP адресами) - 4323;

- переглядів сторінок у wikispaces.com- 10355.

\begin{tabular}{|c|c|c|c|c|}
\hline \multirow{2}{*}{$\begin{array}{l}\text { Member Name } \\
\because \text { Alena } 27\end{array}$} & \multicolumn{2}{|c|}{ Edits } & \multicolumn{2}{|c|}{ Messages } \\
\hline & 1 & RSS B. & 1 & RSS D. \\
\hline Borispolov & 17 & RSS B. & 6 & RSS S \\
\hline Fy buga1978 & 67 & RSS S. & 48 & RSS SD \\
\hline Wil elearn23 & 2 & RSS D. & 44 & RSS D. \\
\hline Al kovalenka & 1 & RSS S & 3 & RSS \\
\hline 슈 kukharenko & 96 & RSS S & 17 & RSS S \\
\hline W Lubov_Panchenko & 2 & RSS S & 5 & RSS SD \\
\hline 됼 NinaLyulkun & 21 & RSS SA & 28 & RSS Din \\
\hline ENina_aka_nagora & 54 & RSS S. & 51 & RSS A \\
\hline hatshishinalar & 2 & RSS Si & 1 & RSS D. \\
\hline & & & -1 & of 10 \\
\hline
\end{tabular}

Діяльність активних учасників: (перша колонка - кількість редагувань ресурсів курсу, друга - кількість повідомлень, залишених в курсі на Wikispaces.com

Таблиия 1

Кількість інформаційних ресурсів, запропонованих слухачам відкритого дистанційного курсу «Соціальні сервіси у дистанційному навчанні»

\begin{tabular}{|c|c|c|}
\hline Кількість тижнів & $\begin{array}{c}\text { Посилань на } \\
\text { інформаційні } \\
\text { ресурси для } \\
\text { вивчення }\end{array}$ & $\begin{array}{c}\text { Посилань на } \\
\text { записи вебінарів } \\
\text { для перегляду }\end{array}$ \\
\hline Тиждень № 1 & 86 & 3 \\
\hline Тиждень № 2 & 53 & 4 \\
\hline Тиждень № 3 & 45 & 6 \\
\hline Тиждень № 4 & 34 & 0 \\
\hline Тиждень № 5 & 59 & $\mathbf{2 1}$ \\
\hline Тиждень № 6 & 32 & $\mathbf{3 0 9}$ \\
\hline ВСЬОГО &
\end{tabular}


Діяльність активних учасників дистанційного курсу «Соціальні сервіси у дистанційному навчанні»: (перша колонка - кількість повідомлень у власних блогах, друга - кількість повідомлень, залишених у соціальному сервісі Twitter

\begin{tabular}{|c|c|c|}
\hline Кількість тижнів & Блоги & Twitter \\
\hline Тиждень № 1 & 24 & 41 \\
\hline Тиждень № 2 & 22 & 21 \\
\hline Тиждень № 3 & 14 & 17 \\
\hline Тиждень № 4 & 35 & 23 \\
\hline Тиждень № 5 & 8 & 91 \\
\hline Тиждень № 6 & 9 & $\mathbf{2 4 5}$ \\
\hline ВСБОГО & $\mathbf{1 1 2}$ & \\
\hline
\end{tabular}

Слід зазначити, що статистика цього дистанційного курсу наведена виключно щодо термінів його проведення. Але й після закінчення курсу накопичення i розповсюдження інформації його учасниками продовжується: в твіттері з хештегом курсу \#UkrEl11 опубліковано біля 340 мікроблогів, у закладках Diigo залишено 120 посилань, опубліковано близько 30 статей у блогах учасників (інформація на кінець серпня 2011 року).

Аналіз публікацій західних дослідників і власний досвід участі в масових відкритих дистанційних курсах дозволяс визначити принципи їх побудови (організаціі).

1. Велика кількість учасників. Ці курси відповідають сучасним зрушенням у бік мережевого навчання. Джордж Сіменс і Стівен Доунс, зауважують: «Навчання зараз відбувається через спільноти практиків та персональні мережі....» [16].

2. Масові відкриті курси, як правило, є безкоштовними.

3. На масовий відкритий дистанційний курс завжди відкрита реєстрація незалежно від часу його початку до завершення.

4. Для розміщення основних ресурсів курсу (анотація, методичні вказівки, посилання на основні ресурси), проведення on-line зустрічей i дискусій використовуються сервіси web 2.0 або безкоштовні програмні продукти (програми 3 відкритим кодом). Для створення «материнської сторінки» найчастіше використовуються Googlesites, Wordpress, Wikispases, Moodle.

5. У курсі широко використовуються соціальні мережі (Facebook, Twitter). 
6. Основний інформаційний матеріал знаходиться поза сайтом курсу. Відмінність масових відкритих курсів від LMS (Learning Management System) полягає в тому, що LMS може використовуватися як один із вузлів загальної навчальної мережі, в основному для здійснення управління (наприклад, реєстрації) і проведення дискусійних форумів, що трапляється не завжди. Найбільша активність учасників курсу відбувається за межами основного сайту, на інших вузлах мережі, наприклад, в особистих блогах, інших веб-сайтах, соціальних мережах, відео-хостингах (наприклад, YouTube). Слухачі створюють і передають інформацію за допомогою автоматичних систем, що використовують теги i RSS-канали. Для впорядкування інформаційних потоків використовуються програми-агрегатори (Netvibes, Scoop.it, Paper.li, Tweetedtimes).

7. Планування роботи, як правило, тижневе. Після кожного тижня формується бюлетень роботи за тиждень.

8. Для участі в курсі треба володіти навичками роботи в соціальних мережах і мати досвід використання сервісів web 2.0.

9. У середині масового відкритого курсу можуть виникати внутрішні спільноти, робота яких відповідає загальним принципам відкритих курсів.

10. Після закінчення курсу інформація залишається у всесвітній мережі Інтернет і продовжує поширюватися і доповнюватися його учасниками.

\section{Принципи роботи учасників масових відкритих дистанційних курсів}

1. Для оптимальної роботи курс потребує якомога більше активних учасників. Активна участь слухачів має важливе значення, оскільки важливо розуміти, що, хоча організатори курсу і надають першопочатковий матеріал, проте велика частина змісту курсу формується самими його учасниками.

2. Ролі викладача і слухача в цих курсах майже стираються. Викладач виступає скоріш наглядачем або посередником. Він здебільшого виконує функції орієнтації слухачів, надання їм технічної допомоги, статистичної обробки, фільтрації (або вибору) інформації. Малоймовірно, що організатори будуть мати можливість читати і взаємодіяти з усіма слухачами масових курсів. Організатори курсу не ставлять оцінки, слухачі можуть не виконувати всі практичні завдання. Основна ідея таких курсів - не отримання свідоцтв, а процес навчання i взаємодії 3 іншими учасниками. 
3. Існує кілька видів участі в курсі: активний учасник, учасник кількох тем (дискусій) і спостерігач (читач). Маємо зазначити, що чим більший внесок і участь слухача в курсі, тим більше користі для інших учасників і загалом змісту курсу. Активна участь слухачів дуже часто може виступати каталізатором для активізації діяльності інших. Проте рівень і тип участі повністю залежить від особи слухача.

4. Для роботи в таких курсах слухачеві потрібно мати великий рівень мотивації і самоконтролю. Модель залежить від спроможності учасників управляти як своїм власним навчанням, так i можливістю розвивати свої власні мережі підтримки навчального процесу. Роль слухача полягає не тільки у збиранні

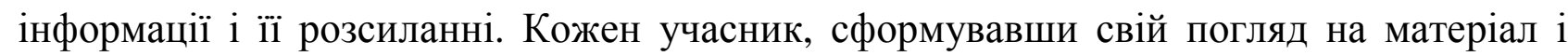
зробивши його доступним для інших слухачів, організаторів та Інтернет спільноти, має бути готовим вступати в безпосередній контакт з іншими щодо свого матеріалу і коментувати матеріал інших слухачів.

5. Учасники самостійно формують свої навчальні цілі і траєкторію навчання.

6. У масових дистанційних курсах існує надлишок інформації. До формальних ресурсів додаються гіперпосилання, обговорення. На їх основі створюються нові ресурси, що може призвести слухача до інформаційного перевантаження. Це перевантаження інколи спонукає слухача до виходу з курсу, тому вони мають бути попереджені про це організаторами.

7. Важливим моментом $є$ принцип вибірковості, тобто треба пояснити слухачам, що читати всі ресурси і відповідати на всі репліки необов'язково з кількох причин. По-перше, інформації дійсно багато і можна фізично все не встигнути, крім того, відповідна інформація може не відповідати навчальним цілям слухача.

Висновки. На наш погляд, у системі МВС масові відкриті дистанційні курси найбільш ефективно можна використовувати в системі підвищення кваліфікації, адже вони розраховані на досвідчених користувачів мережі Інтернет. Традиційний навчальний процес не зовсім підходить для цієї моделі, оскільки учасники самі формулюють цілі навчання i iii траєкторію. Однак можливо використовувати принципи організації цих курсів або самі курси для підтримки традиційного навчального процесу, тим самим готуючи потенційних учасників (споживачів) майбутніх масових курсів. 
До традиційних дистанційних курсів можна додавати діяльність учасників у соціальних мережах (Facebook, Twitter, Wiki), можна об'єднати учасників курсів у відповідні групи на Googlegroups, запропонувати слухачам завести власний блог i планувати діяльність слухачів у цих мережах.

Можливо одразу буде важко досягнути масовості, але слухачі поступово звикатимуть до неформального спілкування, коментування власної i чужої інформації, навчаться шукати інформацію відповідно до цілей навчання, а також працювати з нею (коментувати, змінювати, поширювати, створювати нову).

Масові відкриті дистанційні курси можна організовувати за відповідною юридичною тематикою для фахівців-практиків. Інформація щодо правозастосовної і юридичної діяльності в таких курсах буде формуватися в діалозі, дискусіях, протистоянні, що є важливим з точки зору пошуку істини, а в правоохоронній діяльності набуває особливого змісту і значення.

Отже, можна окреслити місце відкритих дистанційних курсів у діяльності вищих навчальних закладів системи МВС за умови відповідної підготовки до такої діяльності:

- підтримка традиційного навчального процесу;

- підвищення кваліфікації викладачів щодо використання інформаційних технологій у навчальному процесі;

- підвищення кваліфікації викладачів ВНЗ МВС України і практичних працівників ОВС за окремими напрямами правоохоронної діяльності.

Перспективними напрямами подальших досліджень $є$ методика створення $\mathrm{i}$ проведення масових відкритих дистанційних курсів, програмні засоби створення масових відкритих дистанційних курсів.

\section{Список використаних джерел}

1. Towards lifelong education for all - adult education: The 1960s and 1970s towards institutionalization [Електронний pecypc]. - Режим доступу : http://www.unesco.org/education/educprog/50y/brochure/tle/140.htm.

2. Downes Stephen. Connectivism \& Connective knowledge / S. Downes [Електронний ресурс]. - Режим доступу : http://www.huffingtonpost.com/stephendownes/connectivism-and-connecti_b_804653.html. 
3. Siemens George MOOC or Mega-Connectivism Course / G. Siemens [Електронний $\quad$ ресурс]. http://www.itdl.org/Journal/Jan_05/article01.htm.

4. Siemens George Knowing Knowledge / G. Siemens [Електронний ресурс]. Режим доступу : http://www.elearnspace.org/KnowingKnowledge_LowRes.pdf.

5. Associations Should Consider the MOOC [Електронний ресурс]. - Режим доступу : http://www.tagoras.com/2010/09/27/mooc.

6. Sui Fai John Mak MOOC - A solution to Higher Education and Future Learning? / John Mak Sui Fai [Електронний pecypc]. - Режим доступу : http://suifaijohnmak.wordpress.com/2011/08/page/6.

7. You Ready to MOOC? [Електронний pecypc]. - Режим доступу : http://alearning.wordpress.com/2011/08/08/you-ready-to-mooc/.

8. Дистанционный курс: понятие и структура [Електронний ресурс]. - Режим доступу http://distancelearning.ru/db/el/029AA6356FE2F276C3256C5B005AF7DA/doc.html.

9. Про затвердження Положення про дистанційне навчання: Постанова Кабінету Міністрів Украйни від 21 січня 2004 р. № 40 [Електронний ресурс]. - Режим доступу : http://zakon.rada.gov.ua/cgi-bin/laws/main.cgi?nreg=z0464-04.

10. Кухаренко В. М. Розробка дистанційного курсу / В. М. Кухаренко [Електронний ресурс]. www.kneu.kiev.ua/data/upload/news/main/ua/255/kuharenko.ppt.

11. Проект Положення про сертифікацію електронного навчального курсу [Електронний ресурс]. - Режим доступу : http://garmonia.nubip.edu.ua/polojennia.pdf

12. Что такое электронный курс? [Електронний ресурс]. - Режим доступу: http://www.slideshare.net/econsortium/ss-6879791.

13. Бугайчук $K$. Л. Дистанційний курс: поняття та структура [Текст] / К. Л. Бугайчук // Інформатизація ВНЗ МВС України : матеріали наук.-практ. конф. (28 травня 2010 р., Харків). - Х. : ХНУВС, 2010. - С. 21-24.

14. Case study CCK [Електронний pecypc]. - Режим доступу: http://wikieducator.org/OER_university/eduMOOC_planning_group/Case_study_CCK\#Qu estions_we_should_try_answer_in_this_case_study 
15. Benefits and challenges of a MOОС [Електронний ресурс]. - Режим доступу : http://moocguide.wikispaces.com/2.+Benefits+and+challenges+of+a+MOOC.

16. Explore A New Learning Frontier: МООС [Електронний ресурс]. - Режим доступу : http://www.downes.ca/cgi-bin/page.cgi?post=55947.

\section{МАССОВЫЙ ОТКРЫТЫЙ ДИСТАНЦИОННЫЙ КУРС: ПОНЯТИЕ, ОСОБЕННОСТИ ПРОВЕДЕНИЯ И ПЕРСПЕКТИВЫ ИСПОЛЬЗОВАНИЯ В УЧЕБНОМ ПРОЦЕССЕ СИСТЕМЫ МВД}

Бугайчук Константин Леонидович, кандидат юридических наук, доцент, ведущий научный сотрудник научно-исследовательской лаборатории проблем профилактики правонарушений и взаимодействия с населением, Харьковский национальный университет внутренних дел, г. Харьков, e-mail: klbugaychuk@gmail.com

\section{Аннотация}

Поскольку образовательные технологии все больше распространяются через социальные сети и мобильные устройства, возникают попытки найти методики, основанные на этих новых технологиях для улучшения учебного процесса - массовые открытые дистанционные курсы являются одним из таких форматов. Автором статьи проанализирована сущность и структура массовых открытых дистанционных курсов, а также особенности их проведения. На основе анализа публикаций зарубежных исследователей и собственного опыта, сформулированы принципы построения и деятельности участников массовых открытых дистанционных курсов. Также в статье определены основные направления применения массовых открытых дистанционных курсов в образовательной деятельности системы МВД Украины.

Ключевые слова: учебный процесс, массовый открытый дистанционный курс, коннективизм.

\section{MASS OPEN ONLINE COURSES: CONCEPTS, FEATURES AND PROSPECTS OF THE USE IN EDUCATIONAL PROCESS OF MIA}

Konstantin L. Bugaychuk, $\mathrm{PhD}$, docent, Senior researcher, Research laboratory on crime prevention and interaction with the population, Kharkov National University of Internal Affairs, Kharkov, e-mail: klbugaychuk@gmail.com 


\section{Resume}

As educational technologies are more spread through social networks and mobile devices, there are attempts to find methods that are based on these new technologies to improve the educational process - the mass open online courses is one of these formats. The author of the article examines the nature and structure of the mass open online courses, as well as features of their conduct. Based on analysis of foreign publications and research experience there are formulated principles and activities of the participants of the mass open online courses. This article also outlines the main directions of application of the mass open online courses in the educational activities of the Ministry of Internal Affairs of Ukraine.

Keywords: educational process, mass open online course, connectivism.

Матеріал надійшов до редакції 07.10.2011 р. 